\title{
SIKAP BAHASA DAN PEMBELAJARAN BAHASA INDONESIA DI PERGURUAN TINGGI
}

\author{
Umar Mansyur \\ Fakultas Sastra, Universitas Muslim Indonesia \\ umar.mansyur@umi.ac.id
}

\begin{abstract}
Abstrak
Undang-Undang Nomor 24 Tahun 2009 pasal 25 disebutkan Bahasa Indonesia merupakan jati diri bangsa, kebanggaan nasional, sarana pemersatu berbagai suku bangsa, serta sarana komunikasi antardaerah dan antarbudaya daerah. Maka dari itu, sebagai pemakai bahasa Indonesia selayaknya memiliki rasa kebanggaan menggunakan bahasa Indonesia. Namun di lingkup perguruan tinggi, sikap berbahasa yang positif belum sepenuhnya dimiliki oleh sebagian besar mahasiswa. Kesadaran rasa setia, bangga memiliki, dan memelihara bahasa Indonesia tampaknya masih kurang. Hal ini disebabkan mahasiswa cenderung bersikap lebih percaya diri ketika menggunakan bahasa asing dibandingkan dengan bahasa negeri sendiri. Dalam konteks pembelajaran Bahasa Indonesia, tugas tersebut malah hanya dibebankan kepada para guru dan dosen Bahasa Indonesia. Paradigma seperti ini semestinya dapat diubah karena membiasakan menggunakan bahasa Indonesia secara baik dan benar akan menuai hasil yang maksimal dalam peningkatan prestasi akademik mahasiswa. Pemahaman bahasa Indonesia sesuai dengan kaidah berbahasa Indonesia yang baik dan benar diperlukan bagi mahasiwa agar mempunyai sikap yang positif dalam menggunakan bahasa Indonesia. Sikap berbahasa Indonesia yang positif dapat ditunjukkan dalam bentuk kesetiaan berbahasa, kebanggaan berbahasa, dan kesadaran adanya norma bahasa.
\end{abstract}

Kata Kunci: Sikap bahasa, pembelajaran bahasa Indonesia, perguruan tinggi

\section{PENDAHULUAN}

Bahasa Indonesia yang berkedudukan sebagai bahasa nasional dan bahasa resmi negara harus terus dibina dan dikembangkan agar menjadi bahasa yang modern, yakni bahasa yang sanggup mengemban fungsinya sebagai sarana komunikasi dalam berbagai segi kehidupan. Dalam usaha membina dan mengembangkan bahasa Indonesia tersebut, pemerintah menjadikan bahasa Indonesia sebagai salah satu bidang studi wajib. Tujuan pembinaan bahasa Indonesia melalui pendidikan formal tersebut di samping bermaksud agar mahasiswa memiliki keterampilan berbahasa lisan maupun tulisan dengan baik, juga diharapkan memiliki jati diri dan kepribadian yang yang luhur.

Sebagai pemakai bahasa Indonesia selayaknya memiliki rasa kebanggaan menggunakan bahasa Indonesia sebagai alat komunikasi. Setiap warga negara Indonesia juga sepatutnya memiliki sikap positif terhadap bahasa Indonesia dan berusaha agar selalu cermat dan teratur menggunakannya dalam kehidupan sehari- 
hari. Paling tidak menanamkan budaya malu jika tidak mampu menggunakan bahasa Indonesia secara baik dan benar. Oleh karena itu, sudah sepantasnyalah bahasa Indonesia dicintai dan dijaga.

Namun demikian, di lingkup perguruan tinggi misalnya, sikap berbahasa yang positif belum sepenuhnya dimiliki sebagian besar mahasiswa. Kesadaran rasa setia, bangga memiliki, dan memelihara bahasa Indonesia tampaknya masih kurang. Hal ini disebabkan mahasiswa cenderung bersikap lebih percaya diri ketika menggunakan bahasa asing dibandingkan dengan bahasa negeri sendiri. Sikap seperti ini tercermin dalam kehidupannya sehari-hari, baik dalam situasi formal maupun nonformal. Jika merujuk pada pernyataan bahwa bahasa menunjukkan jati diri bangsa, maka menurut Hikmat \& Solihati (2013) hal ini menjadi sangat ironis karena di kalangan generasi muda saat ini, jati diri bangsanya mulai keropos dan kelak bisa saja tergerus oleh perkembangan zaman.

Selain itu, pembelajara Bahasa Indonesia di perguruan tinggi terkadang dipandang remeh. Anggapan tersebut muncul karena bahasa Indonesia sudah digunakan sebagai bahasa sehari-hari dalam berinteraksi. Pun bahasa Indonesia juga telah diajarkan sejak berada di bangku sekolah dasar. Maka tak heran jika mata kuliah Bahasa Indonesia dianggap sudah tidak perlu lagi diajarkan. Padahal kedua hal tersebut konteksnya sangat berbeda.

Paradigma di atas tentu saja tidak benar. Bahasa Indonesia yang digunakan sehari-hari berbeda dengan materi yang diberikan dalam pelajaran Bahasa Indonesia. Jika sehari-hari seseorang dapat berbicara dengan sangat lancar kepada lawan bicaranya, itu disebabkan ragam bahasa yang digunakan merupakan ragam bahasa Indonesia tidak resmi. Namun, akan jauh berbeda jika seseorang tersebut menggunakan ragam bahasa Indonesia resmi. Dalam penggunaan sehari-hari, bahasa Indonesia cenderung menggunakan ragam nonformal atau tidak resmi yang sudah mengalami percampuran dengan bahasa daerah pemakai bahasa. Sementara, dalam pembelajaran bahasa Indonesia, hal tersebut tidak dibenarkan karena pembelajaran diarahkan pada keterampilan berbahasa Indonesia secara formal atau resmi.

Berbahasa Indonesia secara baik dan benar memiliki konsekuensi logis terkait terhadap pemakaiannya sesuai dengan situasi dan konteks pembicaraan. Pada situasi formal, menggunakan bahasa Indonesia yang benar menjadi prioritas utama dan pemakaiannya sering menggunakan bahasa baku. Namun, terkadang yang menjadi permalasahan menurut Mansyur (2016) adalah munculnya gejala bahasa, seperi interferensi bahasa gaul, yang tanpa disadari turut dipakai dalam berbahasa Indonesia ragam resmi. Hal ini mengakibatkan bahasa Indonesia yang digunakan menjadi tidak baik. Oleh karena itu, pemahaman bahasa Indonesia sesuai dengan kaidah berbahasa Indonesia yang baik dan benar diperlukan mahasiwa agar mempunyai sikap yang positif terhadap bahasa Indonesia. Sikap berbahasa Indonesia yang positif dapat ditunjukkan dalam bentuk kesetiaan berbahasa, kebanggaan berbahasa, dan kesadaran adanya norma bahasa yang berlaku. 


\section{SIKAP BAHASA}

Sikap dalam bahasa Indonesia (KBBI, 2016) diartikan sebagai perbuatan dan sebagainya yang berdasarkan pada pendirian atau keyakinan. Menurut Rokeach (dalam Sumarsono, 2002) sikap bukan sesuatu yang bersifat sesaat, melainkan sesuatu yang berlangsung dalam jangka waktu yang relatif lama. Sikap adalah jaringan keyakinan (kognisi) dan nilai yang memberikan kepada seseorang untuk berbuat atau bereaksi terhadap suatu obyek dengan cara tertentu yang disenanginya.

Selain itu, Lambert (dalam Chaer, 2010) menjelaskan bahwa sikap terdiri atas tiga komponen, yaitu komponen kognitif, komponen afektif, dan komponen konatif. Komponen kognitif berhubungan dengan pengetahuan mengenai alam sekitar dan gagasan yang biasanya merupakan kategori yang dipergunakan dalam proses berpikir. Sementara itu, komponen afektif menyangkut masalah penilaian baik, suka atau tidak suka, terhadap sesuatu atau suatu keadaan. Adapun komponen konatif menyangkut perilaku atau perbuatan sebagai "putusan akhir" kesiapan reaktif terhadap suatu keadaan.

Selanjutnya, Anderson (dalam Chaer, 2010) membagi sikap atas dua macam, yaitu (1) sikap kebahasaan dan (2) sikap nonkebahasaan, seperti sikap politik, sikap sosial, sikap estetis, dan sikap keagamaan. Kedua jenis sikap ini dapat menyangkut keyakian atau kognisi mengenai bahasa.

Sikap kebahasaan merupakan hal yang penting dalam kaitanya dengan suatu bahasa karena sikap bahasa dapat melangsungkan hidup suatu bahasa. Pada dasarnya bahasa tidaklah bersifat statis, tetapi dinamis. Kedinamisan bahasa disebabkan oleh kedinamisan masyarakat pemakai bahasa. Masyarakat bersifat dinamis dalam arti selalu mengalami perubahan. Perubahan itu tampak dari sikap dan hal-hal yang berhubungan dengan kepentingan masyarakat itu sendiri. Bahasa sebagai tingkah laku verbal merupakan salah satu aspek dari keseluruhan tingkah laku manusia yang sedang berkomunikasi.

Keadaan dan proses terbentuknya sikap bahasa tidak jauh dari keadaan dan proses terbentuknya sikap pada umumnya. Senada dengan hal tersebut, Kridalaksana (2001) menyatakan bahawa sikap bahasa merupakan posisi mental atau perasaan terhadap bahasa sendiri atau bahasa orang lain. Sebagaimana halnya dengan sikap, maka sikap bahasa juga merupakan peristiwa kejiwaan, sehingga tidak dapat diamati secara langsung. Sikap bahasa dapat diamati melalui perilaku berbahasa atau perilaku tutur. Namun, dalam hal ini juga berlaku ketentuan bahwa tidak setiap perilaku tutur mencerminkan sikap bahasa. Demikian pula sebaliknya, sikap bahasa tidak selamanya tercermin dalam perilaku tutur.

Selanjutnya, sikap bahasa menunjukkan senang atau tidaknya seorang penutur bahasa terhadap suatu bahasa. Sikap terhadap sesuatu biasanya akan ada yang positif, jika dinilai baik atau disukai, dan akan negatif jika dinilai tidak baik atau tidak disukai. Begitupu juga dengan sikap terhadap bahasa. Sejalan dengan hal tersebut, Anderson (dalam Chaer, 2010) mengemukakan bahwa sikap bahasa adalah tata 
keyakinan atau kognisi yang relatif berjangka panjang, sebagian mengenai bahasa, mengenai objek bahasa, yang memberi kecenderungan kepada seeorang untuk bereaksi dengan cara tertentu yang disenanginya.

\section{SIKAP TERHADAP BAHASA INDONESIA}

Sikap terhadap bahasa Indonesia adalah anggapan atau pandangan seseorang terhadap bahasa Indonesia, apakah senang atau tidak terhadap bahasa tersebut, sehingga sikap bahasa tersebut berpengaruh terhadap pemilihan bahasa. Sikap terhadap bahasa Indonesia juga dapat dikelompokkan ke dalam dua bagian, yakni (1) sikap positif dan (2) sikap negatif.

Sikap positif bahasa Indonesia adalah penggunaan bahasa Indonesia sesuai dengan kaidah bahasa dan sesuai dengan situasi kebahasaan. Sikap bahasa Indonesia yang positif hanya akan tercermin apabila si pemakai mempunyai rasa setia untuk selalu memelihara dan mempertahankan bahasanya sebagai sarana untuk berkomunikasi. Sikap positif terdapat pada seseorang yang mempunyai rasa bangga terhadap bahasanya sebagai penanda jati diri. Seseorang yang mempunyai sikap positif terhadap bahasa Indonesia cenderung akan menerima bahasanya dengan segala kelebihan dan kekurangan secara terbuka, tanpa merasa kurang percaya diri jika dibandingkan dengan bahasa lain. Sebaliknya, ia justru akan merasa bangga karena merasa memiliki bahasa sendiri.

Menurut Pateda (1987), seorang pemakai bahasa dikatakan bersikap positif apabila derajat kecenderungannya bertindak dengan meningkat terhadap bahasa bahasanya. Perilakunya mencerminkan rasa tanggung jawab, rasa memiliki, sikap menghormati, dan berkemauan untuk membina dan mengembangkan bahasanya tersebut. Rasa tanggung jawab seseorang atau sekelompok orang terhadap suatu bahasa ditandai beberapa hal sebagai berikut:

1. Selalu berhati-hati menggunakan bahasa tersebut.

2. Tidak merasa senang melihat orang memakai bahasanya secara serampangan.

3. Memperingatkan dan mengoreksi pemakai bahasa lain kalau ternyata membuat kekeliruan.

4. Perhatiannya tertarik kalau orang menjelaskan tentang hal-hal yang berhubungan dengan bahasa.

5. Berusaha menambah pengetahuan tentang bahasa tersebut.

6. Bertanya kepada ahlinya kalau menghadapi persoalan bahasa.

Sementara itu, sikap negatif terhadap bahasa Indonesia akan menyebabkan orang kurang peduli terhadap usaha pembinaan dan pelestariaan bahasa Indonesia. Mereka menjadi tidak bangga memakai bahasa sendiri sebagai penanda jati diri, bahkan merasa malu memakai bahasa Indonesia. Selain itu, sikap negatif terhadap bahasa terbentuk apabila orang yang bersangkutan sudah mengetahui atau sudah diberi tahu bahwa ia telah melakukan kesalahan, tetapi enggan untuk 
memperbaikinya. Orang yang terampil berbahasa dapat menunjukkan sikap positif jika ia belajar dari kesalahan, memperhatikan saran, petunjuk, atau pendapat orang ahli, serta mengupayakan perbaikan pemakaian bahasanya.

Beberapa bentuk sikap negatif yang masih terjadi di tengah-tengah masyarakat Indonesia antara lain:

1. Bangga memperlihatkan kemahirannya berbahasa Inggris, meskipun penguasaan bahasa Indonesianya masih kurang.

2. Merasa dirinya lebih pandai daripada yang lain karena telah menguasai bahasa asing dengan fasih, sekalipun penguasaan bahasa Indonesianya kurang sempurna.

3. Merasa malu apabila tidak menguasai bahasa asing, tetapi tidak pernah merasa malu apabila tidak menguasai bahasa Indonesia.

4. Menganggap remeh bahasa Indonesia dan tidak mau mempelajarinya karena merasa dirinya telah menguasai bahasa Indonesia dengan baik.

Adanya sikap negatif terhadap bahasa Indonesia dapat diubah menjadi sikap bahasa Indonesia yang positif. Hal ini selaras yang dikemukakan Halim (dalam Chaer, 2010) bahwa cara yang dapat ditempuh untuk mengubah sikap negatif itu menjadi sikap bahasa yang positif adalah dengan pendidikan bahasa yang dilaksanakan atas dasar pembinaan kaidah dan norma bahasa, disamping normanorma sosial dan budaya yang ada di dalam masyarakat bahasa yang bersangkutan. Namun, keberhasilan tersebut bergantung pada motivasi belajar yang banyak ditentukan oleh sikap terhadap bahasa yang sedang dipelajarinya.

Sikap berbahasa Indonesia mahasiswa dirumuskan sesuai dengan rumusan mengenai sikap bahasa menurut Garvin \& Mathiot (dalam Chaer, 2010), yang merupakan ciri-ciri sikap yang positif terhadap bahasa. Ciri-ciri sikap bahasa tersebut dirumuskan sebagai berikut:

1. Kesetiaan bahasa (language loyalty) yang mendorong masyarakat suatu bahasa mempertahankan bahasanya dan apabila perlu mencegah adanya pengaruh bahasa lain.

2. Kebanggaan bahasa (language pride) yang mendorong orang mengembangkan bahasanya dan menggunakannya sebagai lambang identitas dan kesatuan masyarakat.

3. Kesadaran adanya norma bahasa (awareness of the norm) yang mendorong orang menggunakan bahasanya dengan cermat dan santun merupakan faktor yang sangat besar pengaruhnya terhadap perbuatan yaitu kegiatan menggunakan bahasa (language use).

\section{TUJUAN PEMBELAJARAN BAHASA INDONESIA}

Dalam dunia pendidikan, khususnya pembelajaran bahasa Indonesia, pelaksanaan pembelajaran berbahasa dikemas ke dalam empat aspek, yakni keterampilan menyimak, membaca, berbicara, dan menulis. Keempat aspek 
keterampilan berbahasa tersebut telah menjadi landasan pembelajaran mulai tingkat sekolah dasar hingga perguruan tinggi. Lebih lanjut, pembelajaran bahasa di perguruan tinggi diarahkan untuk meningkatkan keterampilan mahasiswa dalam berkomunikasi, baik secara lisan maupun tulisan. Kemampuan yang dikembangkan antara lain dari segi kebahasaan, pemahaman, dan penggunaan bahasa Indonesia itu sendiri. Untuk itu, menurut Mansyur (2016), setiap pengajar bahasa Indonesia senantiasa terus berupaya meningkatkan keberhasilannya dalam pembelajarannya, seperti melakukan inovasi-inovasi pembelajaran yang efektif, inovatif, aktif, kreatif, dan menyenangkan.

Mata kuliah Bahasa Indonesia memiliki visi menjadikan bahasa Indonesia sebagai salah satu instrumen pengembangan kepribadian mahasiswa menuju terbentuknya insan terpelajar yang mahir bekomunikasi dalam bahasa Indonesia. Adapun misi mata kuliah Bahasa Indonesia yaitu tercapainya kemahiran mahasiswa dalam menggunakan bahasa Indonesia untuk menguasai, menerapkan, dan mengembangkan ilmu pengetahuan, teknologi dan seni, dengan penuh rasa tanggung jawab sebagai warga negara yang berkepribadian mulia.

Tujuan pembelajaran Bahasa Indonesia di perguruan tinggi tentunya bukan hanya menjadikan mahasiswa lulus dalam ujian mata kuliah Bahasa Indonesia, melainkan mereka harus mampu terampil berkomunikasi menggunakan bahasa Indonesia secara baik dan benar. Mereka dibimbing untuk menguasai aspek-aspek keterampilan berbahasa agar dapat menambah pengetahuan dan pengalamannya dalam berkomunikasi sehari-hari.

Selain itu, mahasiswa diajarkan untuk lebih memahami pada kegiatankegiatan penulisan karya ilmiah dan pengucapan dalam berbahasa Indonesia yang baik dan benar. Pentingnya mempelajari bahasa Indonesia dalam hubungannya dengan ilmu pengetahuan yaitu karena mahasiswa sebagai calon sarjana dipersiapkan tidak hanya untuk menjadi konsumen ilmu pengetahuan, melainkan juga sebagai produsen dalam bidang ilmiah.

Alasan pentingnya lainnya bahasa Indonesia perlu diajarkan di perguruan tinggi karena pembelajaran bahasa Indonesia bertujuan untuk menanamkan rasa cinta dan bangga menggunakan bahasa Indonesia. Setiap jurusan di perguruan tinggi menjadikan Bahasa Indonesia sebagai mata kuliah pengembangan kepribadian yang wajib, karena di perguruan tinggi mahasiswa sering menyusun karya ilmiah, seperti dalam pembuatan makalah, laporan praktikum, makalah, skripsi, dan karya ilmiah lainnya. Dalam penulisan karya ilmiah tersebut tentunya mahasiswa dapat berpedoman pada materi-materi yang telah diajarkan dalam mata kuliah ini.

Tujuan mata kuliah Bahasa Indonesia yang diajarkan di perguruan tinggi antara lain sebagai berikut:

1. Menumbuhkan kesetiaan terhadap bahasa Indonesia yang diharapkan dapat mendorong mahasiswa untuk senantiasa memelihara dan mencintai bahasa Indonesia. 
2. Menumbuhkan kebanggaan terhadap bahasa Indonesia yang diharapkan mampu mendorong mahasiswa agar selalu mengutamakan bahasanya sebagai lambang identitas bangsa.

3. Menumbuhkan kesadaran adanya norma bahasa Indonesia yang diharapkan dapat mendorong mahasiswa agar menggunakan bahasa Indonesia sesuai dengan kaidah dan aturan yang berlaku.

\section{KESIMPULAN}

Sikap bahasa merupakan hal yang penting dalam kaitanya dengan suatu bahasa karena sikap bahasa dapat melangsungkan hidup suatu bahasa. Pada dasarnya bahasa tidaklah bersifat statis, tetapi dinamis. Kedinamisan bahasa disebabkan oleh kedinamisan masyarakat pemakai bahasa. Masyarakat bersifat dinamis dalam arti selalu mengalami perubahan. Perubahan itu tampak dari sikap dan hal-hal yang berhubungan dengan kepentingan masyarakat itu sendiri. Bahasa sebagai tingkah laku verbal merupakan salah satu aspek dari keseluruhan tingkah laku manusia yang sedang berkomunikasi. Pemahaman bahasa Indonesia sesuai dengan kaidah berbahasa Indonesia yang baik dan benar diperlukan bagi mahasiwa agar mempunyai sikap yang positif dalam menggunakan bahasa Indonesia. Sikap berbahasa Indonesia yang positif dapat ditunjukkan dalam bentuk kesetiaan berbahasa, kebanggaan berbahasa, dan kesadaran adanya norma bahasa yang berlaku.

Tujuan pembelajaran Bahasa Indonesia di perguruan tinggi tentunya bukan hanya menjadikan mahasiswa lulus dalam ujian mata kuliah Bahasa Indonesia, melainkan mereka harus mampu terampil berkomunikasi menggunakan bahasa Indonesia secara baik dan benar. Mereka dibimbing untuk menguasai aspek-aspek keterampilan berbahasa agar dapat menambah pengetahuan dan pengalamannya dalam berkomunikasi sehari-hari. Pembelajaran bahasa Indonesia di perguruan tinggi diarahkan untuk meningkatkan keterampilan mahasiswa dalam berkomunikasi, baik secara lisan maupun tulisan. Kemampuan yang dikembangkan antara lain dari segi kebahasaan, pemahaman, dan penggunaan bahasa Indonesia itu sendiri.

\section{DAFTAR RUJUKAN}

Chaer, A. \& Agustina, L. (2010). Sosiolinguistik: Perkenalan Awal. Jakarta: PT Rineka Cipta.

Direktorat Jenderal Pendidikan Tinggi. (2013). Materi Kuliah Bahasa Indonesia. Jakarta: Kementrian Pendidikan dan Kebudayaan.

Garvin, P.L. \& Mathiot, M. (1968). The Urbanization of the Guarani Language: A Problem in Language and Culture. In Readings in the Sociology of Language (pp. 365-374).

Hikmat, A. \& Solihati, N. (2013). Bahasa Indonesia untuk Mahasiswa S1 \& Pascasarjana, Guru, Dosen, Praktisi, dan Umum. Jakarta: Grasindo. 
Kemendikbud. (2016). Kamus Besar Bahasa Indonesia Daring. Jakarta: Badan Pengembangan dan Pembinaan Bahasa.

Kridalaksana, H. (2001). Kamus Linguistik. Jakarta: PT. Gramedia Pustaka Utama.

Mansyur, Umar. (2016). Inovasi Pembelajaran Bahasa Indonesia melalui Pendekatan Proses. Retorika: Jurnal Bahasa, Sastra, dan Pengajarannya, 9(2), 158-163.

Mansyur, Umar. (2016). Bahasa Indonesia dalam Belitan Media Sosial: Dari CabeCabean Hingga Tafsir Al-Maidah 51. http://doi.org/10.17605/OSF.IO/7VPJH Sumarsono \& Partana, Paina. (2002). Sosiolinguistik. Yogyakarta: Sabda.

Undang-Undang Nomor 24 Tahun 2009 tentang Bendera, Bahasa, dan Lambang Negara, serta Lagu Kebangsaan. 